\title{
Customer Satisfaction Regarding Private Sector Banks in Gujarat
}

\author{
Md. Intekhab Rahman Galib ${ }^{a}$, Utsho Chakraborty ${ }^{b}$, Haimanti Biswas', Sowrav Saha ${ }^{d}$, Dr. Sheshang Degadwala \\ aUG Scholar, BBA, Gujarat University, Ahmedabad, India \\ bUG Scholar, Computer Engineering, Sarvajanik College of Engineering and Technology, Surat, India \\ 'UG Scholar, Information Technology, Sigma Institute of Engineering, Vadodara, India \\ dUG Scholar, Civil \& Infrastructure Engineering, Adani Instiute Of Infrastructure Engineering, Ahmedabad, \\ India
}

eAssociate Professor and Head of Department, Computer Engineering Department, Sigma

Institute of Engineering, Vadodara, India

\begin{abstract}
This paper attempts to measure and find out the quality of services and customer satisfaction level in terms of private sector banks. The paper also slightly shows the comparison between Public sector and Private sector banks related to the customer satisfaction. The research is based on Gujarat which is a state of India. Data collection, data formulation and structuring and data interpretation is based on 423 samples. In terms of private sector banks ICICI, IDBI, HDFC, AXIS Bank, YES Bank, RBI Bank, Kotak Mahindra Bank, IDFC Banks are taken as they are market leaders. ATM facility, Online banking facility, Mobile Banking Facility, Current account, Fixed Deposit, Saving Account, Physical Environment, Competitive Interest Rate etc. has been taken as parameters. From the research, it has been found that there is relationship between service quality and customer satisfaction. We are living in digital era. Almost all the banks are trying to acquire and implement digital facilities. From our research, we also found that majority of the clients are satisfied with mobile banking, online banking and ATM services of the private sector banks. The paper also reveals that the clients are not much satisfied with the behavior of the bank staff of the public sector banks. Age, gender, occupation of the clients are also taken into consideration while preparing the paper.
\end{abstract}

Keywords : Private Sector Banks, Mobile Banking, Online Banking, Saving Account, Current Account, Fixed Deposit, Interest Rate.

\section{INTRODUCTION}

The banking world has assumed a new dimension at the dawn of 21st century with the advent of online banking. Generally, banking sector maybe classified as retail banking and corporate banking. Retail banking actually is designed and structured to meet the requirements of individual customers and to encourage their savings, includes payment of their utility bill, consumer loans, credit cards, checking account. On the other hand, corporate banking works to fulfill the need of corporate customers like bills, discounting, opening letters of credit, managing cash etc. 
Metamorphic changes took place in the Indian financial system during the eighties and nineties consequent as a result of deregulation and liberalization of economic policies of the government. India started shaping up its economy and earmarked ambitious plan for economic growth. Gradually, a huge change in money and capital market took place. Strategic application of the marketing concept in the banking sector was introduced to increase the customer satisfaction. The privatization policy of banking services aims at encouraging the competition in banking sector and to introduce financial services. Gradually, services such as Demit service, internet banking, portfolio management, venture capital etc. came into existence to satisfy the needs of the public. An important mission for every banker today is to ensure greater operational efficiency and customer satisfaction.

The introduction of the marketing concept to banking sectors can be traced back to the American Marketing Association conference which was held in 1958. Marketing of Banking can be defined as the part of management activity, which seems to direct the flow of banking services profitability to the customers. The marketing concept actually requires that there should be thorough understanding of customer needs and preference and to learn about market It operates in. Further the market needs to be segmented so as to understand the requirements of the customers at a profit to the banks.

\section{DEFINITION OF BANKING}

(C.R, 1990) According to the Oxford Dictionary; "An establishment for the custody and safety of money, which it pays out, on a customer's order."

According to whitehead;

"A bank can be defined as an institution which collects and accumulates surplus funds from the public, safeguards them, and ensure the availability for the true owner when required and also lends sums to those who are in need of funds and can provide security."

Banking company in India has been defined in the Banking Companies Act 1949, "The institution which transacts and run the business of banking which means accepting, for the purpose of lending or investment of the deposits of money from the public, repayable on demand or otherwise withdrawable by means of cheque, draft, order or otherwise."

The banking system is an important subsystem of the financial system. It works as an important channel of collecting small savings from the households and lending it to the corporate sector.

The Indian banking system has Reserve Bank of India $(\mathrm{RBI})$ as the apex or highest body for all matters relating to the banking systems. It is the central or main bank of India. It is also known as the banker to all other banks.

\section{EVOLUTION OF INDIAN BANKING}

Ancient or old banking system of India constituted of indigenous bankers. They have been carrying on their age-old banking activities in different parts of the country under different names. The modern age of banking constitutes the fundamental basis of economic and financial growth. The term bank is being used since long time but there is no clear idea regarding its beginning. Italian money lenders were known as "Banchi" because they were used to keep a special type of table to conduct the transaction of their business.

\section{IMPORTANCE OF BANK IN BUSINESS}

On the basis of these Important Functions of Banks, we can easily describe and discuss the importance of banks in today's global life. 
[1] TO COLLECT SAVINGS AND TO ADVANCE LOANS

Accepting deposit and to advance the loans is the basic and one of the main functions of commercial banks. On this function, all other functions depend accordingly. Bank operates various types of accounts for their customers.

\section{[2] MONEY TRANSFER}

Banks have facilitated the making of payments from one place to another place or one person to another person by means of cheque, bill of exchange and drafts instead of cash. Payment as the cheque, draft is more safe and convenient, Especially in terms of huge payments, this facility is very much helpful for traders and businessmen. It really increase the importance of banks for business community.

\section{[3] ENCOURAGES SAVINGS}

Banksperforminvaluableservicebyencouragingsavings amongthepeople.Theyencourage them to save for profitable investment for themselves and for the benefit of the nation. These savings also helps in capital formation.

\section{[4] TRANSFER SAVINGS INTO INVESTMENT}

Bank transfer the collected savings into investment and thus enhance the amount of effective capital, which helps the process of economic and financial growth.

\section{[5] OVERDRAFT FACILITIES}

The banks allow the overdraft facilities to their trusted customers and thus help them in overcoming of temporary financial problems.

\section{[6] DISCOUNTING BILL OF EXCHANGE}

Importance of banks can be seen through providing the facility of discounting bill of exchange. Banks discount their bill of exchange of consumers and help them to overcome the financial difficulties and problems. Through discounting the bill of exchange, they are able to get the desire amount for investment they want.

\section{[7] FINANCING INTERNAL AND EXTERNAL TRADE}

Banks also help the merchants and traders in financing internal and external business by discounting foreign bill of exchange, issuing of letter of credit and other guarantees to their customers.

\section{[8] ACT AS AN AGENT}

The bank also act as an agent or medium and help their customers in the purchase and sales of shares, provision of lockers payment of monthly and dividends on stock.

\section{[9] ISSUE OF TRAVELLER'S CHEQUE}

For the convenience, safety and security of money, bank provides the facility of traveller's cheques for the tourists or travelers. These cheques help the travelers and tourists to meet their expenses during their visit, as these are granted by issuing bankers, restaurants, and other businessmen both at home and abroad. Thesis one of the most prestigious functions of banks and shows the importance of banks for us in more precise ways.

\section{[10] GENERAL UTILITY SERVICES}

Existence of commercial banks is very much important for contribution to general prosperity. Banks are the main components in raising the level of economic development of the world. In addition to the above-cited advantages, banks also provide various types of services of general utilities to the customers and the general public. 


\section{LITERATURE REVIEW}

(Anis ali, 2018)(Puja K)Puja K and Yukti reveals that private sector banks are successfully maintaining quantity level of it's customers by providing better banking services and facilities. Private sector banks have more satisfied and loyal customers. In any economy, innovative and creative technologies and changing expectations of markets, considerations of quality of each and every service is important to increase customers satisfaction level.

Success mantra must be customer centric orientation, where the customer relationship management with its customers in private sector banks has been successful in achieving its goals. However, public sector banks must need to improve in the area of dealing with the customers and also need to work and conduct activities in swift motion. Equipped with latest technology, developed infrastructure and well-trained employees, convenient office hours and locations of the branches are the factors or important components affecting customers satisfaction level.

(Mishra US)Mishra US, Sahoo KK, Mishra S and Patra SK (2010) explained that quality of service, customers satisfaction, customers retention, customers loyalty etc. are the main challenges to attract tend retain loyal customers in banking sector. Among all, customers satisfaction playing an important role in attracting, retaining loyal customers. The private sector banks are executing and implementing pure banking activities. On the other hand, public sector banks are needed to conduct some social responsibilities.

The most facilities availed and preferred by the customers are ATM, Demat A/C and Foreign transfer of funds. In the mean time, private sector bank customers are using internet or phone banking by ATM/Debit card which is very much helpful for them.
Private sector banks should concentrate on the lower income group customers, also because the higher income group found the services provided by banks to be more effective but high service charges, which is out of the reach of the lower income group of customers.

Private sector banks are competing with the public sector banks in the field of capital adequacy, asset quality, management efficiency, earning quality etc.

Further,(ME.) Doddaraju ME concluded that It is very much needed to give special training to the employees those who are working in rural areas directly dealing with the customers. Private sector

Bank customers are more satisfied and loyal to their banks because of their multiple branches in different convenient locations and also for technological facilities.

Customer care services of the private sector banks are far better than public sector banks. Treating the customers with good behavior is a specialty and must needed activity of the private sector banks. Private sector banks provide speedy and easy money transfer and transaction facility.

Nowadays, people are more curious of having bank account sand conducting banking activities in private sector banks.

\section{III.OBJECTIVEOF STUDY}

\section{Research Problems}

Banking sector in any nation is the vital and most important factor for the development of the business and economy. Banks are considered as the heart of the business sector of any economy and supply the necessary money blood to all the business organizations and simultaneously support and help the weaker sectors or the organizations of a nation. 
Customers' satisfaction is the elemental factor or component that decides the success of any bank. Now a days, Private and Public sector banks are expanding their branches and offices in urban as well as in the rural areas to get more and more customers. Branch size, services, infrastructure, facilities, staff, working hours etc. is varying on the basis of governing ownership and the location of the branch i.e. Private sector and Public sector or Rural and Urban branch. So, there is need to assess the satisfaction level of customers from Private and Public sector Banks or Rural and Urban areas to provide the suggestions for the improvement of services and other tangibles of the banks.

\section{Research Objectives}

The objectives of the research are as follows:

To know the satisfaction level of the customers from Private sector banks.

To find out the banking sector that is largely availed by the customers.

To find out services which is mostly used by the customers.

To provide suggestions to improve the satisfaction level of the customers.

\section{RESEARCH METHODOLOGY}

Research is an art of scientific investigation and to find out suitable and fruitful solution. In other word research is a scientific and systematic work for pertinent information on a specific or definite topic. The logic behind taking research methodology into consideration is that one can have knowledge about the method and procedure adopted for achievement of objectives of the project. With the adoption of this others can evaluate or measure and find out the results also. Its main aim or purpose is to keep the researchers on the right track
Research Design:

Research design can be defined as a blue print or frame work of research project. It contains all the important information which are needed to solve the research problems.

Descriptive research has been applied; Descriptive research is used to describe characteristics and features of a population or phenomenon being studied. A descriptive study is one in which information is collected or accumulated without changing the environment.

\section{Sources of Data:}

There are main 2 sources of data collection. That is
1. Primary data
2. Secondary data

Primary data Instruments:

Questionnaire:

- We collected primary data by sending links to the customers through questionnaire.

Secondary data source:

- We collected secondary data with the help of internet facility through which we collected lots of information.

\section{Sampling Method:}

- Sampling techniques means the method which we used for selecting the sample from population.

- In our study we are using convenience sampling technique because it is the least expensive and least time consuming method as well as we can get right respondents at right place and on right time.

Sample Size: 423

Sample sizes of 423 customers from various places were taken for the research purpose. Out of that 155 have public account, 177 have private account, and 91 have both the account. 
Research instruments:

We have conducted a survey through questionnaire. A structured technique for data collection that consist of a series of questions that a respondent answers.

Scope:

This study is for all the customers who are using bank. It is mainly focusing on the satisfaction level of the customers of private banks.

\section{DATA ANALYSIS AND INTREPRETATION}

\section{1) AGE AND GENDER}

\begin{tabular}{|c|c|c|c|c|}
\hline \multicolumn{2}{|c|}{} & \multicolumn{2}{c|}{ Gender } & \multirow{2}{*}{ Total } \\
\cline { 3 - 5 } \multicolumn{2}{|c|}{} & Female & Male & \\
\hline \multirow{4}{*}{ Age } & Below 18 & 9 & 10 & 19 \\
\cline { 2 - 5 } & $18-25$ & 139 & 143 & 282 \\
\cline { 2 - 5 } & $26-30$ & 24 & 33 & 57 \\
\cline { 2 - 5 } & $31-40$ & 20 & 16 & 36 \\
\cline { 2 - 5 } & $41-50$ & 12 & 11 & 23 \\
\cline { 2 - 5 } & 50 above & 1 & 5 & 6 \\
\hline \multicolumn{7}{|c}{ Total } & 205 & 218 & 423 \\
\hline
\end{tabular}

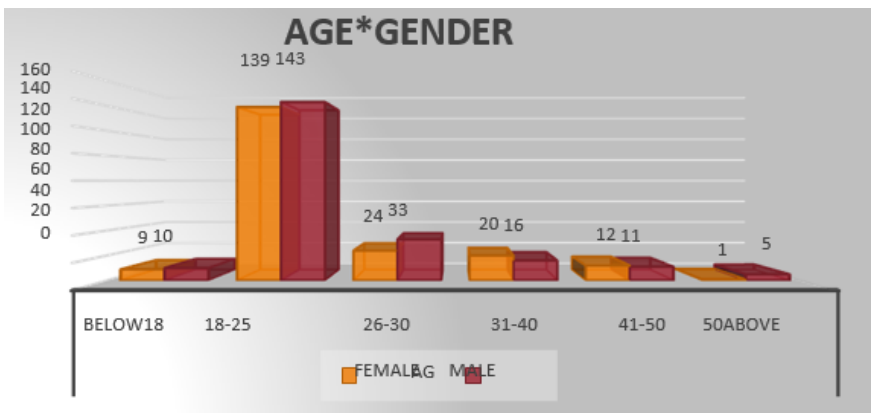

INTERPRETATION:

- From the above chart we can interpret that out of 423 customers, between the age scale of 18-25, there are 139 from female category and 143 from male category.

- Between the age scale of 26-30, 24 are female and 33 are male.

- There are 20 female and 16 male between age scale of31-40
- Between the age scale of 41-50, 12 are female and 11 are male.

- There is 1 female and 5male. Above 50 years

\section{2) OCCUPATION OF RESPONDENT:}

\begin{tabular}{|c|c|c|c|}
\hline \multicolumn{2}{|c|}{ Occupation } & Frequency & Percent \\
\hline \multirow{4}{*}{ Occupation } & Businessman & 26 & $6.1 \%$ \\
\cline { 2 - 4 } & Housewife & $\mathbf{2 1}$ & $\mathbf{5 . 0} \%$ \\
\cline { 2 - 4 } & Job & 100 & $23.6 \%$ \\
\cline { 2 - 4 } & Professional & 32 & $7.6 \%$ \\
\cline { 2 - 4 } & Student & $\mathbf{2 4 4}$ & $57.7 \%$ \\
\cline { 2 - 4 } & Total & 423 & $100 \%$ \\
\hline
\end{tabular}

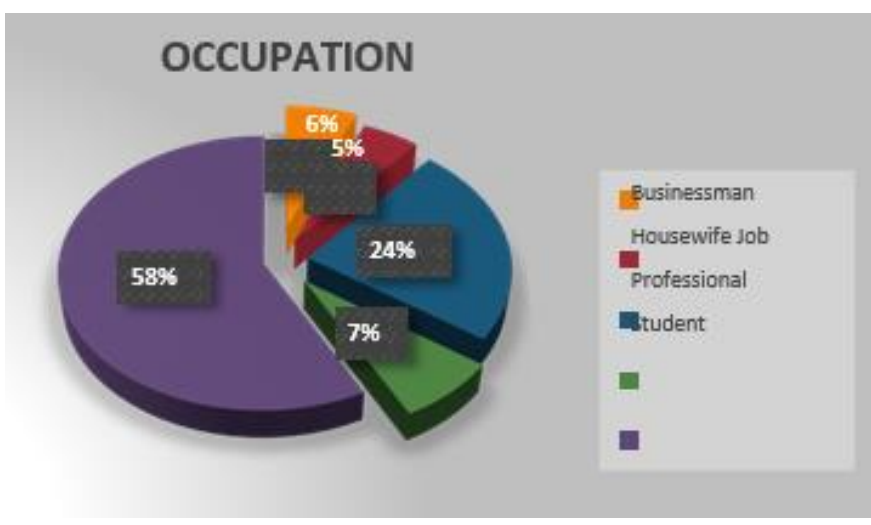

\section{INTERPRETATION:}

- From the above given chart we can interpret that out of 423 customers, 26(6.1\%) are businessman, $21(5.0 \%)$ are housewife, $100(23.6 \%)$ are pursuing jobs, 32(7.6\%) are from different professions and $244(57.7 \%)$ are students.

3) ACCOUNT PREFERENCE OFRESPONDENT:

\begin{tabular}{|l|l|l|}
\hline ACCOUNT PREFERENCE \\
\hline & Frequency & Percent \\
\hline Both & 91 & $21.5 \%$ \\
\hline Private & $\mathbf{1 7 7}$ & $\mathbf{4 1 . 8} \%$ \\
\hline Public & 155 & $36.6 \%$ \\
\hline Total & 423 & $100 \%$ \\
\hline
\end{tabular}




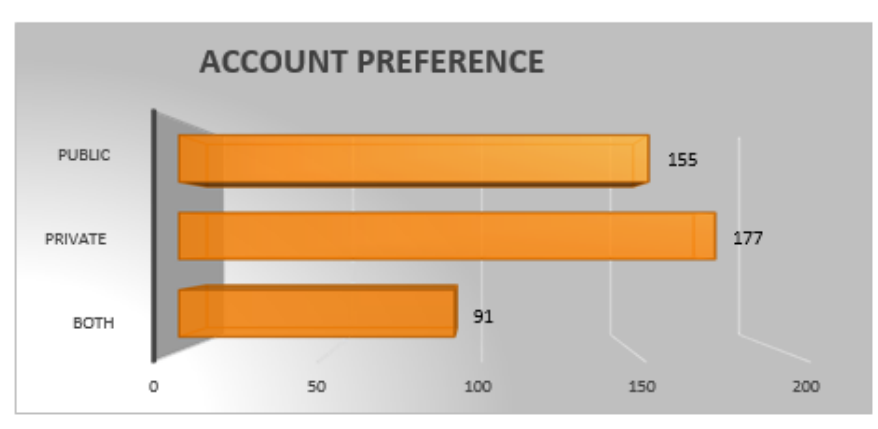

\section{INTERPRETATION:}

- Out of 423 respondents, there are $177(41.8 \%)$ customers whose preference is private bank.

- 155 (36.6\%) customers are preferring public bank

- 91 (21.5\%) customers have both public and private account.

4) MOST PREFERRED BANK OF RESPONDENT:

\begin{tabular}{|l|l|}
\hline BANK & YES \\
\hline ICICI & 67 \\
\hline HDFC & 69 \\
\hline AXIS & 56 \\
\hline KOTAK & 38 \\
\hline YES & 22 \\
\hline IDFC & 7 \\
\hline IDBI & 9 \\
\hline RBL & $\mathbf{4}$ \\
\hline OTHER & $\mathbf{7 6}$ \\
\hline
\end{tabular}

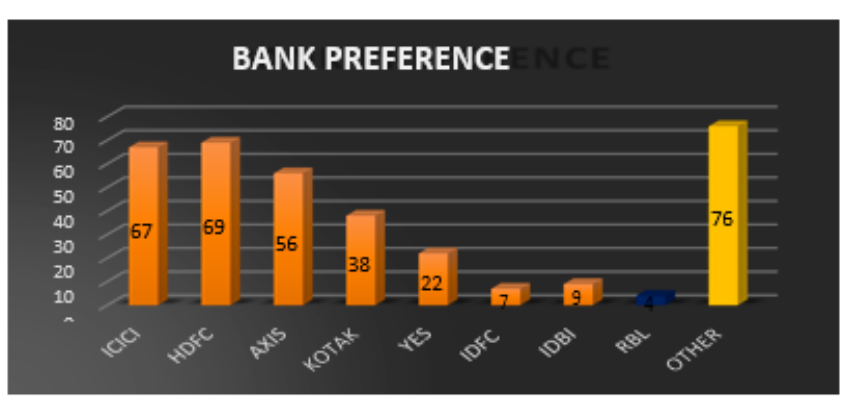

\section{INTERPRETATION:}

From the above chart, there are 67 respondents who are using ICICI bank, 69 in HDFC bank, 56 in AXIS bank, 38 in KOTAK bank, 22 in YES bank, 7 in IDFC bank, 9 in IDBI bank, 4 in RBL bank and the remaining i.e. OTHER banks with 76 respondents.

5) CONSUMER SATISFACTION:

\begin{tabular}{|l|l|l|}
\hline CONSUMER SATISFACTION & TOTAL & RANK \\
\hline SERVICE AT YOUR BANK & 964 & 3 \\
\hline ONLINE BANK FACILITY & 990 & 1 \\
\hline PHYSICAL ENVIRONMENT & 941 & 5 \\
\hline $\begin{array}{l}\text { BANK AND CUSTOMER } \\
\text { RELATIONSHIP }\end{array}$ & 973 & 2 \\
\hline COMPLAINING & 918 & 6 \\
\hline PREVENTING FRAUD & 950 & 4 \\
\hline
\end{tabular}

\begin{tabular}{rlllll|}
\hline 1000 & & 990 & & & \\
980 & 964 & & 973 & \\
960 & & & 941 & & 918 \\
940 & & & & & \\
920 & & & & & \\
900 & & & & & \\
880 & & & & \\
\hline
\end{tabular}

INTERPRETATION:

- Highest number of people are satisfied with the ONLINE BANKING services of the banks with a rating of 990 out of 1000 and ranked 1st among all the service

- Bank and customer relationship, Service at the respective banks, Preventing fraud, Physical environment, Complaining factors are ranked 2nd, 3rd, 4th, 5th and 6th position consecutively on the basis of the rating.

\section{6) SERVICES MOSTLY USED BYRESPONDENT:}

\begin{tabular}{|l|l|l|l|l|l|l|l|l|l|l|}
\hline SERVICES & ICICI & HDFC & AXIS & KOTAK & YES & IDFC & IDBI & RBL & OTHER & RANK \\
\hline $\begin{array}{l}\text { INTERNET } \\
\text { BANKING }\end{array}$ & 43 & 54 & 41 & 25 & 11 & 4 & 5 & 2 & 25 & 3 \\
\hline ATM & 67 & 70 & 32 & 32 & 18 & 4 & 5 & 3 & 44 & 1 \\
\hline DEMATE & 9 & 13 & 12 & 6 & 6 & 3 & 1 & 2 & 15 & 7 \\
\hline $\begin{array}{l}\text { MOBILE } \\
\text { BANKING }\end{array}$ & 38 & 44 & 39 & 28 & 14 & 3 & 5 & 4 & 25 & 4 \\
\hline SAVING & 49 & 60 & 44 & 27 & 12 & 3 & 5 & 4 & 40 & 2 \\
\hline CURRENT & 23 & 18 & 21 & 9 & 10 & 2 & 4 & 3 & 15 & 5 \\
\hline FD & 19 & 21 & 9 & 12 & 9 & 4 & 4 & 3 & 14 & 6 \\
\hline
\end{tabular}




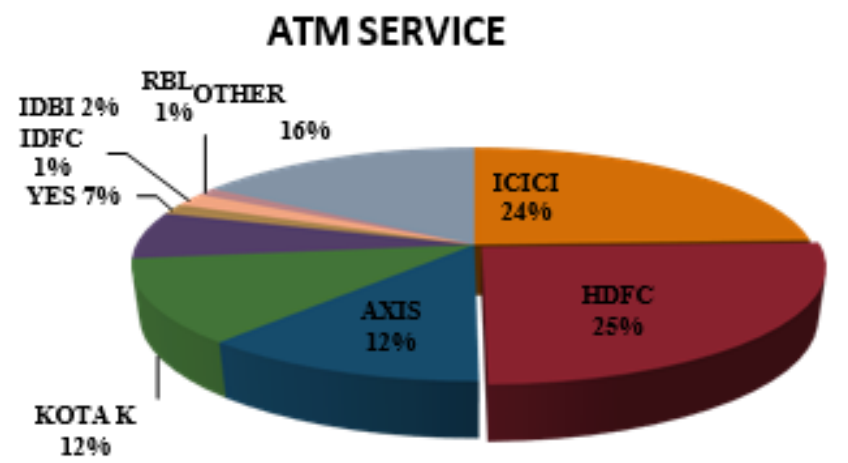

INTERPRETATION:

- Out of all the services, ATM service is on the lead.

- It is mostly used in $\operatorname{HDFC}(25 \%)$, than ICICI(24\%), OTHER(16\%), KOTAK and AXIS with (12\%), YES(7\%), IDBI(2\%), and IDFC AND RBL with(1\%).

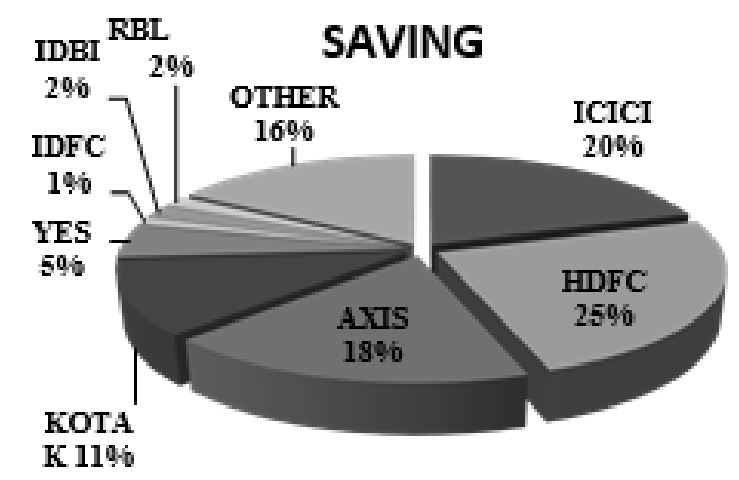

INTERPRETATION:

- The 2nd rank has been alloted to the SAVING Account.

- It is mostly used in $\operatorname{HDFC}(25 \%)$, than $\operatorname{ICICI}(20 \%)$, OTHER(16\%), AXIS with (18\%), KOTAK(11\%), YES(5\%), IDBI and RBL with (2\%), and IDFC(1\%).

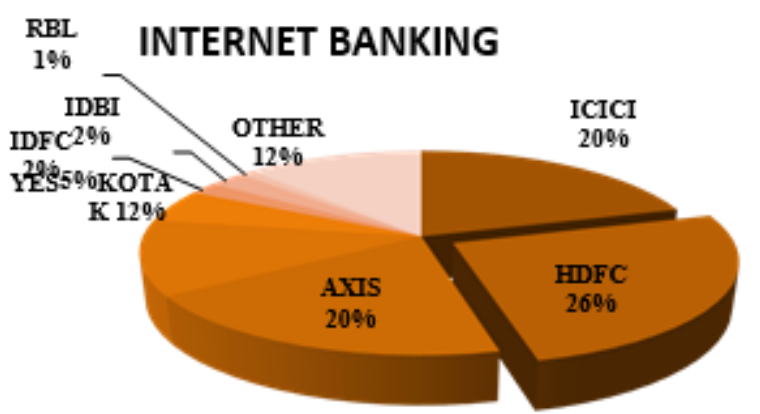

\section{INTERPRETATION:}

- The 3nd rank has been alloted to the INTERNET Banking

- It is mostly used in $\operatorname{HDFC}(26 \%)$, than ICICI and AXIS with (20\%) , OTHER and KOTAK with(12\%), YES(5\%), IDBI and IDFC(2\%), RBL with(\%)

\section{MOBILE BANKING}

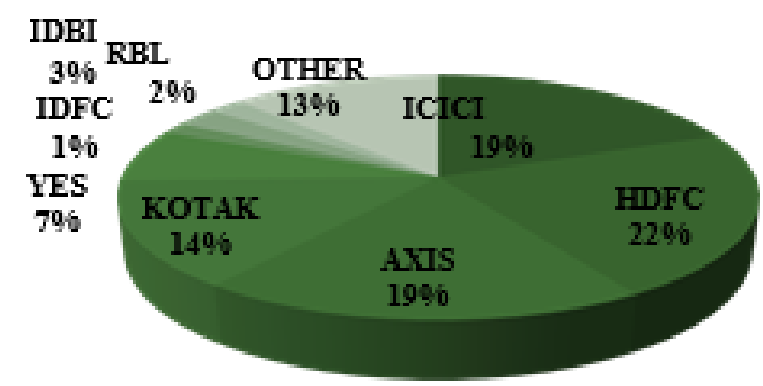

INTERPRETATION:

- MOBILE Banking has been ranked as 4th.

- It is mostly used in HDFC (22\%), than ICICI and AXIS with (19\%), KOTAK with(14\%), OTHER(13\%) ,YES(7\%), IDBI(3\%), RBL with (2\%),IDFC(1\%).

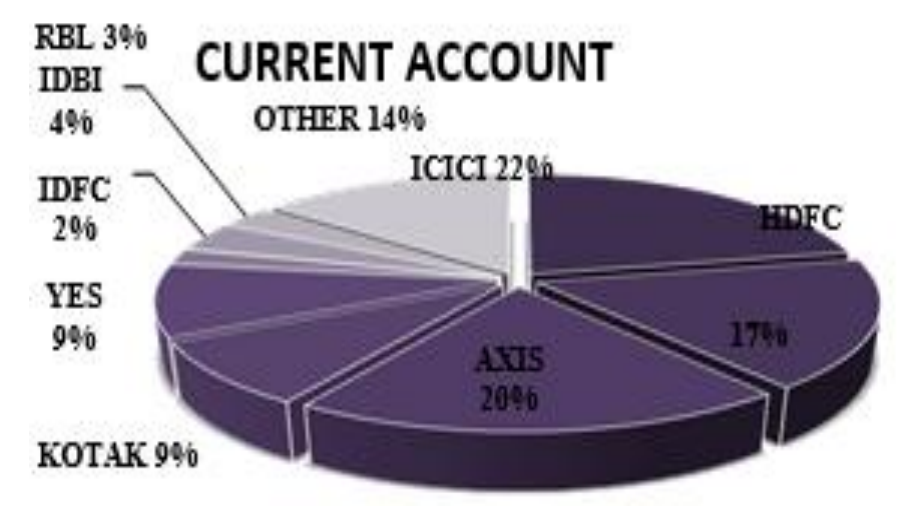

INTERPRETATION:

- CURRENT Account has been ranked as 5th.

- It is mostly used in ICICI(22\%), AXIS with (20\%), HDFC(17\%), OTHER(14\%) KOTAK and YES with (9\%), IDBI(4\%), RBL with (3\%),IDFC(2\%) 


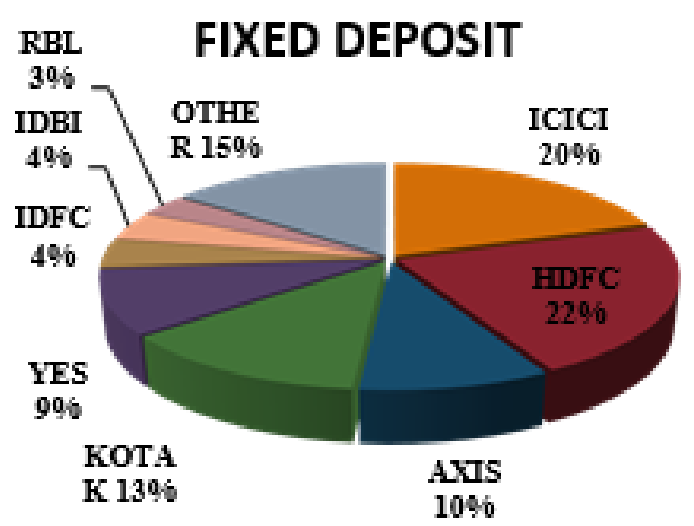

INTERPRETATION:

- FIXED DEPOSIT has been ranked as6th.

- It is mostly used in $\operatorname{HDFC}(22 \%)$, ICICI(20\%), OTHER(15\%), KOTAK(13\%),AXIS with (10\%), YES with (9\%), IDBI(4\%) and IDFC(4\%), RBL with(3\%).

\section{DEMATE SERVICE}

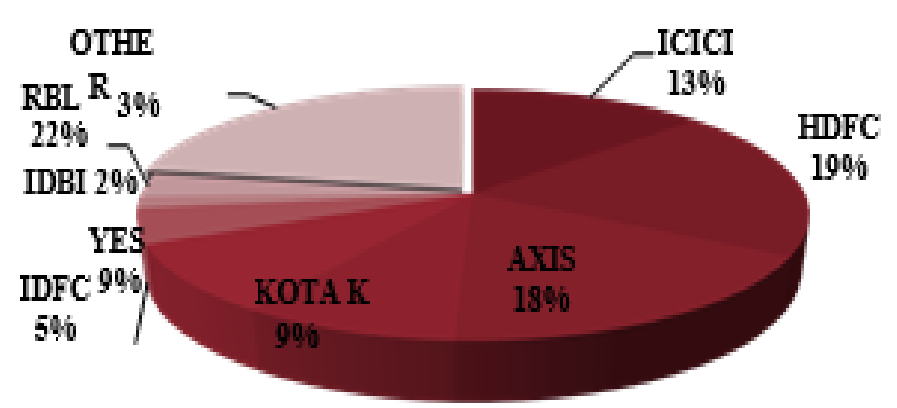

INTERPRETATION:

- DEMATE Service has been ranked as7th

- It is mostly used in OTHER(22\%), HDFC(19\%), ICICI(13\%), AXIS with (18\%), KOTAK and YES with (9\%), IDFC(5\%), RBL with (3\%),IDBI(2\%).

7) YOUR BANK CHARGE UNNECESSARIL Y FOR NOT MAINTAINING MINIMUM BALANCE:

\begin{tabular}{|l|l|l|}
\hline \multicolumn{3}{|c|}{ MAINTAINING MINIMUM BALANCE } \\
\hline & Frequency & Percent \\
\hline Public & 155 & $36.6 \%$ \\
\hline & & \\
\hline Agree & 166 & $39.2 \%$ \\
\hline Disagree & 102 & $24.1 \%$ \\
\hline & & \\
\hline Total & 423 & $100 \%$ \\
\hline
\end{tabular}

MAINTAININGMINIMUM BALANCE

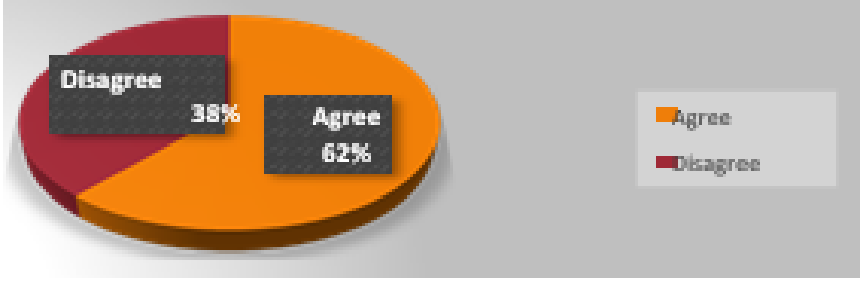

INTERPRETATION:

- From the above chart, we can interpret that out of 423 customers, $62 \%$ of respondents have agreed that the bank charges excessive for not maintaining the minimum balance.

- $38 \%$ of respondents have disagreed that the bank charges excessive for not maintaining the minimum balance.

8) DOES YOUR BANK OFFER COMPETITVE RATE?

\begin{tabular}{|c|c|c|}
\hline \multicolumn{3}{|c|}{ INTEREST RATE } \\
\hline & Frequency & Percent \\
\hline Public & 155 & $36.6 \%$ \\
\hline No & 69 & $16.3 \%$ \\
\hline Yes & 199 & $46.9 \%$ \\
\hline Total & 423 & $100 \%$ \\
\hline
\end{tabular}

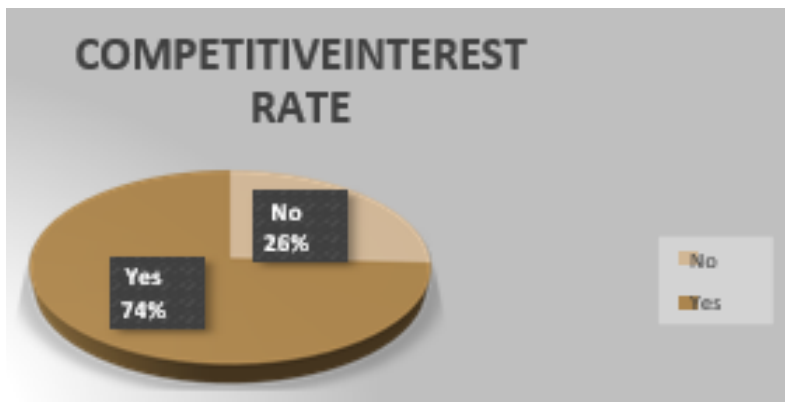




\section{INTERPRETATION:}

- Out of 423 customers, 199(74\%) customers believe that the bank offer competitive interest rate to them.

- Whereas $69(26 \%)$ customers feel that the bank does not offer competitive interest rate.

9) YOUR BANK FULFILL ALL YOUR BANKING NEEDS

\begin{tabular}{|l|l|l|}
\hline \multicolumn{3}{|l|}{ FULFILL BANKING NEEDS } \\
\hline & Frequency & Percent \\
\hline Public & 155 & $36.6 \%$ \\
\hline & & \\
\hline Agree & 241 & $\mathbf{5 6 . 8} \%$ \\
\hline Disagree & 27 & $6.4 \%$ \\
\hline & & $100 \%$ \\
\hline Total & 423 & \\
\hline
\end{tabular}

\section{FULFILLING BANKING NEEDS}

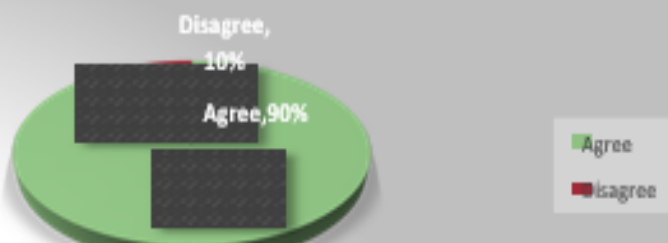

\section{INTERPRETATION:}

- Out of 423 respondents, 241(90\%) of customers agree that their bank fulfils all their banking needs.

- $27(10 \%)$ of customers disagree that their bank does not fulfils their banking needs.

\section{VI.FINDINGS:}

- On the basis of the research work, it is found that there are 205 females and 218 male out of 423respondents.

- Highest number of respondents is collected between the age scale of 18-25.
- Out of occupation, highest number of respondents were students with $57.7 \%$

- We also found that out of 423 respondents, there are 177 customers who are using private account, 155 using public account, and 91 customers are using both.

- The most preferred bank is the OTHER bank, followed by HDFC, ICICI etc.

- As per ratings of satisfaction, consumer has showed great satisfaction in ONLINE BANK FACILITY, followed by BANK AND CUSTOMER RELATONSHIP, SERVICE AT BANK, PREVENTING FRAUD, PHYSICAL ENVIRONMENT AND LAST IS COMPLAINING.

- The services that is mostly used as per this research is ATM SERVICE, followed by SAVINGS ACCOUNT, INTERNET BANKING, MOBILE BANKING, CURRENT ACCOUNT, FIXED DEPOSIT, and lastly DEMATE SERVICE.

- It is also found that $62 \%$ of customers agreed that the bank charges excessive for not maintaining the balance in account.

- Also, 74\% of customers feel that the bank offer competitive interest rate.

- $90 \%$ of the customers agree that their bank fulfils all their banking needs.

\section{RECOMMENDATIONS:}

$62 \%$ of customers agree that the bank charges excessive for not maintaining the balance. Bank should limit the charges as it is posing a great inconvenience to the customers.

- It is found that, there are $26 \%$ of customers who feel that the bank is not offering competitive interest rate. Bank should take necessary steps forthis.

- $10 \%$ of customers has disagree that their bank does not fulfils their banking needs. 
- As per suggestions collected by customers through questionnaire, people have complained about poor delivery of services, the bank should make some efforts to deliver fast services to its customers.

- Customers want their banks to improve its ATM and Cash deposit services. Bank shouldmaintaintheirATMmachinesandseetoitth attheirisenoughcashavailableat ATM.

- As per research, 27.4\% of customers would switch to different bank. The bank should make the available changes stated in the above phase in order to maintain their customers and their trust.

- The staff should be cooperative, friendly and must be capable of understanding the problems of customers.

- Customers generally complain that full knowledge is not granted to them. Thus the bank should properly disclose the features of the services to its customers. Moreover door to door services can also be introduced by bank.

\section{LIMITATIONS}

- Though we have put enough efforts in preparation of our research paper, it might not give the exact picture of the realistic details of the market.

- Researchers are mostly of undergraduates students and not adequately trained for research. This poses a problem to the quality of work.

- This survey is limited to some specific area only.

- As not all respondents would have been able to understand the questionnaire correctly or misread the questions so there is a little chance of marking wrong answers or incorrect choices.

\section{IX.CONCLUSION}

The customers now a days are not only concerned about what type of service is being provided by the banks in India but in the world as a whole. They expect much more facilities than what is actually being provided. So the new coming banking sector has to provide and cater to all the necessary needs of the customers otherwise it is difficult to survive in the competition in the near future. They not only expect or desire and hope for the safety of money but also the best way to invest that money which needs to be fulfilled. Banks need to have a better outlook towards to what customers are actually requiring. Entries of the private sector banks have made the competition tougher and more difficult. If a bank is not functioning properly it will be closed. So it is difficult to handle these types of conditions. Here a simple philosophy can work that customers are considered as God and we need to follow this to survive and serve better. The banking sector is poised for explosive growth and development. In this, scenario, it is imperative that banks adopt technology at an aggressive Pace, if they wish to remain competitive. In the prevailing scenario, a number of banks have adopt a new deployment strategy of infrastructure outsourcing, to lower the cost of service channels. As a result, other banks too will need to align their reinvented business models. The required changes at both the business and technology levels are enormous. In a highly competitive banking markets, early adopters are profiting from increased efficiencies

\section{REFERENCES}

[1]. Anis A, Ratwani B. Customers' satisfaction in Indian banks: Problems and solutions. Int J Econ Res 2017;14:69-76.

[2]. Dash A, Patra SK. Service quality and customer satisfaction: An empirical investigation on public sector banks in Odisha. J Res Mark 2014;2:113-118. 
[3]. Gill HS, Arora S. Study of customer satisfaction: A comparison of public and private banks. Pacific Bus Rev Int 2013;6:74-79.

[4]. Anita. A comparative study of public and private sector banks of India in regard to customer satisfaction. Int J Rev Sur Res 2014;3:1-11.

[5]. Paul J, Mittal A, Srivastav G. Impact of service quality on customer satisfaction in private and public sector banks. Int J Ban Mark 2016;34:606-622.

[6]. Singh K, Gupta N. Customer's perception and satisfaction towards services of public \& private sector banks. Int J Manag 2016;7:77-88.

[7]. Bhatia K, Chouhan N, Joshi N. Comparative Study of Performance of Public and Private Sector Bank. Int J Core Eng Manag 2015;2:306317.

[8]. Kumar J, Thamil SR. Performance evaluation of selected public and private banking sectors through camel model in India. Int J App Bus Econ Res 2016;14:5643-5649.

[9]. Doddaraju ME. A study on customer satisfaction towards public and private sector banking services. Glo J Manag Bus Stud 2013;3:287-294.

[10].Malyadri P, Sirisha S. An analytical study on trends and progress of Indian banking industry. J Bus Fin Aff 2015;4:136.

[11].Mishra US, Mishra BB, Praharaj S, Mahapatra R. CRM in banks: A comparative study of public and private sectors in India. Euro J Soci Sci 2011;24:265-277.

[12].Mishra US, Sahoo KK, Mishra S, Patra SK. Service quality assessment in banking industry of India: A comparative study between public and private sectors. Euro J Soci Sci 2010;16:663679.

[13].Nirmal JV, Prabhjot KM. Customer Satisfaction: A comparative analysis of public and private sector banks in India. Info Know Manag 2012;2:1-7.
[14].Parasuraman A, Berry LL, Zeithaml VA. Servqual: A multiple-item scale for measuring consumer perceptions of service quality. J Ret 1988;64:12.

[15].Puja K, Yukti A. Comparative study of customer satisfaction in Indian public sector and private sector banks. Int J Eng Manag Sci 2010;1:42-51.

[16].Puri J, Yadav SP. Performance evaluation of public and private sector banks in India using DEA approach. Int J Oper Res 2013;18:91-121.

[17].Seema S. Using servqual to assess the customer satisfaction level: A study of an urban cooperative bank. J Eco Pub Fin 2016;2:57-85.

[18].Umma S, Mir AS. Customer satisfaction: A comparative analysis of public and private sector banks in Bangladesh. Euro J Bus Manag 2013;5:1-7.

[19].Vijay PG, Agarwal PK. Comparative study of customer satisfaction in public and private sector banks in India. Glob J Bus Manag 2013;7:15-26.

[20].Anis ali, 1. b. (2018, october 21). customers satisfaction in public and private account. Retrieved from www.alliedacademics.com.

[21].C.R, k. (1990). Retrieved from www.knowledgestom.com.

[22].ME., D. (n.d.). Doddaraju ME. A study on customer satisfaction towards public and private sector banking services. Glo J Manag Bus Stud 2013;3:287-294.

[23].Mishra US, S. K. (n.d.). Mishra US, Sahoo KK, Mishra S, Patra SK. Service quality assessment in banking industry of India: A comparative study between public and private sectors. Euro J Soci Sci 2010;16:663-679.

[24].PujaK,Y.A.(n.d.).PujaK,YuktiA.Comparativestu dyofcustomersatisfactioninIndianpublicsector and private sector banks. Int J Eng Manag Sci2010;1:42-51.

[25].Viraniyan. (2010, AUGUST 13). SCRIBD. Retrieved from www.scribd.com. 